\title{
History as Fiction: D. M. Thomas's The White Hotel as an Example of Historiographic Metafiction
}

\author{
Kurgu Olarak Tarih: Bir Tarih Yazımcı Üstkurmaca Örneği Olarak D. M. \\ Thomas'ın Beyaz Otel Romanı
}

\section{Elzem NAZLI*}

\begin{abstract}
D. M. Thomas's The White Hotel (1981) narrates the personal history of Lisa Erdman who is mercilessly murdered in the Babi Yar massacre in 1941. The aim of this paper is to analyze the ways D. M. Thomas uses history in The White Hotel and discusses the main concern of the novel regarding history and its presentation. In order to make such an analysis, this paper will make use of the arguments in the seminal work of Linda Hutcheon, A Poetics of Postmodernism: History, Theory, Fiction (1988), in which she illustrates the properties of "historiographic metafiction" - a category encompassing the postmodern novel whose basic motivation is to question the paradigms of traditional historiography. The White Hotel offers an experimental handling of traditional historical representation by dealing with the Holocaust as an historical event. In line with Hutcheon's argumentations, this study claims that through its metafictional qualities, The White Hotel deconstructs all the techniques and methods on which traditional historiography builds itself. The characteristics that The White Hotel embodies - viz., it blends reality and fiction, problematizes traditional notions of subjectivity, self-reflexively incorporates overtly different literary forms and styles, and employs an unconventional plot structure - contribute significantly to its status as an example of historiographic metafiction. The employment of these experimental techniques inevitably leads the reader to think about the functions of these techniques, the writing process of the novel, as well as the writing process of history in general.
\end{abstract}

Keywords: D. M. Thomas, The White Hotel, Linda Hutcheon, Historiographic metafiction, Traditional historiography.

$\ddot{\mathbf{O} z}$

D. M. Thomas'ın Beyaz Otel (1981) adlı romanı 1941'de "Babi Yar" katliamında acımasızca katledilen Lisa Erdman'ın bireysel tarihini anlatır. Bu makalenin amac1, D. M. Thomas'ın Beyaz Otel romanında tarihi nasıl kullandığını analiz etmek ve bu romanın tarihe, tarihin betimlenmesine ilişkin temel kaygısının ne olduğunu tartışmaktır. Böyle bir analizi yapmak için Linda Hutcheon'in ufuk açıcı bir eseri olan A Poetics of Postmodernism: History, Theory, Fiction (1988)'daki argümanlarından faydalanılacaktır. Hutcheon bu eserinde, geleneksel tarih yazımı paradigmalarını sorgulayan, postmodern romanları da içine alan bir kategori olan "tarih yazımcı üstkurmaca”nın özelliklerini açıklar. Tarihi bir olay olan Yahudi Soykırımı ile ilgilenen Beyaz Otel geleneksel tarih, tasvir biçimlerini deneysel bir şekilde ale alır. Linda Hutcheon'ın savları doğrultusunda bu çalışma, Beyaz Otel'in üstkurmaca özellikleri dolayısıyla geleneksel tarih yazımının dayandığı tüm metodların ve tekniklerinin yap1 sökümünü yaptığını iddia eder. Beyaz Otel'in kurgu ve gerçeği iç içe geçirmesi, öznellik kavramının geleneksel algılanış biçimini sorunsallaştırması, açık bir biçimde farklı edebi tarzları ve üslupları kendini yansıtan bir şekilde kullanması, geleneksel olmayan bir olay örüntü yapısını işe koşması gibi özelliklerin onun tarih yazımcı üstkurmaca'nın bir örneği olarak tanımlanmasına katkı sağlar. Bütün bu deneysel tekniklerin işe koşulması ise okuyucuyu kaçınılmaz olarak bu tekniklerin işlevlerini, romanın yazım sürecini ve daha genel boyutta ise tarih yazım sürecini düşünmeye iter.

Anahtar Kelimeler: D. M. Thomas, Beyaz Otel, Linda Hutcheon, Tarih yazımcı üstkurmaca, Geleneksel tarih yazımı.

In its most general sense, historiography is the study of the writing process of history. The nineteenth-century was the classical age of history writing emerging as an academic discipline. Leopold von Ranke, the famous German historian, was the most prominent historian who helped history to gain the status of an academic discipline. This is the time when history found its basic methodology, which is called "traditional" in this paper. Traditional history writing is structured around positivist, scientific, and empiricist ideals. The represented historical events and their narration by the historian are associated with the truth. The historian acts as a scientist during this process by supporting the presentation with evidence such as documents, diaries, artifacts, etc. There is a strict division between factual and fictive details.

* Arş. Gör. Orta Doğu Teknik Üniversitesi, Yabancı Diller Eğitimi Bölümü, enazli@metu.edu.tr.

Nazl1, E. (2019). History as Fiction: D. M. Thomas's The White Hotel as an Example of Historiographic Metafiction, Gaziantep University Journal of Social Sciences, 18(1), 13-28, Submission Date: 13-07-2018, Acceptance Date: 22-01-2019.

Araştırma Makalesi. 
With the advent of postmodern thought, however, history writing took a different turn. "Postmodern thought," as Christopher Butler claims, "by analyzing everything as text and rhetoric, tended to push hitherto autonomous intellectual disciplines in the direction of literature" (2002, p. 32). In the second half of the twentieth-century, many philosophers of history and literary critics - such as Hayden White, Linda Hutcheon, Alun Munslow, and Keith Jenkins - appealed to the role of historiography in the constitution of historical facts. Concerning this, the nineteenth-century's ideals of historiography were subjected to close scrutiny by various scholars, and the vehicles used in traditional writing were problematized. Empiricist ideals were challenged by transgressing the boundaries between fact and fiction. Contrary to the traditional understanding of the historian whose relation to historical events and to reality is never questioned, in postmodern understanding, the historian does not appear as an authority figure, but $\mathrm{s} / \mathrm{he}$ is self-conscious about the writing process like a fiction writer. The evidence is treated as text rather than as a tool to reach the truth. The narrative structure of traditional history is foregrounded to show the fictionality of traditional historical works. Thus, history is treated as a literary artefact rather than a scientific work. The problematization of the sharp distinction between traditional and postmodern historiography is a recurrent formal and thematic issue in many postmodern novels.

Congruent with the discussions concerning the notion of historiography above, this study zooms on in D. M. Thomas's The White Hotel (1981). A novelist, poet, and translator D. M. Thomas is a very notable figure in the literature of postmodernist fiction. In this regard, his most renowned postmodernist novel The White Hotel was shortlisted for the Booker Prize in 1981. The White Hotel is mainly about the personal history of Lisa Erdman who is mercilessly murdered in the Babi Yar massacre in 1941. The White Hotel is so multi-layered a novel that since the time of its publication, it has been a great concern for many scholars and critics. It embraces a wide range of issues, such as the relationship between literary genres, history and fiction, reality and fantasy, modernity and postmodernity, psychoanalysis and history, and the Holocaust and art. The range of issues can also be extended to psychoanalysis and myth, death and sexuality, the individual and the community, woman and war, and memory and reality. As all this suggests, this is a very rich novel open to a wide variety of perspectives. This paper, however, will only look at the novel in terms of its handling of history writing. It analyzes the ways The White Hotel uses history and discusses the main concern of the novel regarding history and its presentation. In order to make such an analysis, this paper will make use of the seminal work of Linda Hutcheon, A Poetics of Postmodernism: History, Theory, Fiction (1988), in which she illustrates the properties of "historiographic metafiction" - a category encompassing the postmodern novel whose basic motivation is to question the paradigms of traditional historiography. The White Hotel offers an experimental handling of traditional historical representation by dealing with the Holocaust as an historical event. In line with Hutcheon's argumentations, this study claims that The White Hotel deconstructs all the techniques and methods on which traditional historiography builds itself through its metafictional qualities. The characteristics that The White Hotel embodies - viz., it blends reality and fiction, problematizes traditional notions of subjectivity, self-reflexively incorporates overtly different literary forms and styles, and employs an unconventional plot structure - contribute significantly to its status as an example of historiographic metafiction. The employment of these experimental techniques inevitably leads the reader to think about the functions of these techniques, the writing process of the novel, as well as the writing process of history in general.

Historiographic metafiction refers to the novels that "engage and unveil the parallels between writing literature and historiography suggesting that both are acts of construction that do not reflect or naively represent reality or the past, but (re)invent and shape them from 
necessarily subjective and ideologically laden perspectives" (Butter, 2011, p. 626). The shift in focus towards the writing process of history entails the problematization of traditional historiography; the writing process of fiction is considered "parallel" with the process of history writing in historiographic metafictional novels. The focus towards the process of history writing is the reason why Hutcheon uses "historiographic" in her label. In a further elaboration of the term, Hutcheon states that historiographic metafiction refers to "those well-known and popular novels which are both intensely self-reflexive and yet paradoxically also lay claim to historical events and personages" (1988, p. 5). So these novels self-consciously include both historical facts and fictive elements at the same time. This characteristic of historiographic metafictional novels finds its expression in the term "metafiction" in her labelling. Therefore, it is possible to conclude that historiographic metafictional novels are both historical and metafictional; to put it differently, the problematizing of traditional historiography is achieved through the mode of metafiction. The prominent novelists who write in accordance with this conceptualization are, as they are exemplified by Linda Hutcheon in A Poetics of Postmodernism, John Fowles, Jeannette Winterson, D. M. Thomas, Salman Rushdie, Julian Barnes, Gabriel García Márquez, and Peter Ackroyd, among many others.

Given that historiographic metafiction refers to the novels which problematize the conventional methods of history writing in the mode of metafiction, it seems reasonable to elaborate on the definition of metafiction. The prefix "meta" usually means "above" or "beyond" ("meta-"). When "meta" is combined with "fiction," it may be referred to as "fiction beyond fiction," or it can be claimed that it is beyond what is expected from fiction. The term metafiction, as pointed out by Patricia Waugh in her book entitled Metafiction: The Theory and Practice of Self-Conscious Fiction (1984), is "the fictional writing which self-consciously and systematically draws attention to its status as an artefact in order to pose questions about the relationship between fiction and reality" (p. 2). Thus metafiction is a mode of writing which makes the problematization of the relationship between fiction and reality possible by constantly referring to its process of construction. In traditional realist fiction, the idea that language "passively reflects the objective world" is dominant; in metafiction, this credo is a matter of question. The questions in metafictional novels are directed towards "the well-made plot, chronological sequence, the authoritative omniscient author, the rational connection between what characters 'do' and what they 'are', the causal connection between 'surface' details and the 'deep', 'scientific laws' of existence' in realist fiction" (Waugh, 1984, p. 7). From a related perspective, Linda Hutcheon applies these problematic areas to the writing of history. That is why she labels the postmodernist historical novel as historiographic metafiction.

Before moving into the analysis of the novel in terms of historiographic metafiction, it would be useful to provide a synopsis of the novel. The protagonist Lisa Erdman is a patient of the fictional Sigmund Freud. ${ }^{*}$ The novel includes Lisa's first engagement with Freud in 1919 and ends where Lisa is brutally murdered in the Babi Yar massacre. The White Hotel is made up of a prologue and six chapters. "The Prologue," which is written in the form of epistolary narrative, includes correspondence belonging to the early twentieth-century between Sigmund

\footnotetext{
*D. M. Thomas states in the "Author's Note" that "the role played by Freud in this narrative is entirely fictional" although his imagined Freud "abide[s]" by some factual details about the historical figure Freud and his case history (1981, p. vii). Additionally, throughout this study, Freud will be accepted as a fictional character unless expressed otherwise.
} 
Freud, Sandor Ferenczi ${ }^{\dagger}$ Hanns Sachs, ${ }^{\ddagger}$ and Herr Kuhn. ${ }^{\S}$ These letters are mainly about Freud's patient who suffers from "a severe sexual hysteria" (Thomas, 1981, p. 11). The first chapter of the novel, "Don Giovanni," is a first-person account of Frau Anna G., ${ }^{* *}$ in which she displays her hysteria through exaggerated pornographic fantasies and hallucinations in poetic form. Then follows, in "The Gastein Journal," an extended prose version of the same poem, written in thirdperson narration authored again by the patient herself. The next section, "Frau Anna G.," is Freud's case study of Anna G., the writer of the poem and the journal. Following this chapter, in "The Health Resort," Frau Elisabeth Erdman's life, starting from 1929 to 1936, as well as her correspondence with Freud, is narrated in third-person in the fashion of traditional realism. The next chapter, "The Sleeping Carriage," is set in Kiev during the Second World War on 2930 September 1941, when the massacre of Babi Yar happened and where "more than 30.000" people died (Quinn, 2004, p. 37). In that sense, this chapter is about the last days of Lisa and Kolya, her stepson. The last chapter of the novel, "The Camp," written in third-person, seems to be set either in actual Palestine or heaven, where all the dead and wounded come back to life.

Hutcheon states that in historiographic metafiction, the distinction between the historical and the fictional is blurred. She claims that history and fiction, previously regarded as different genres, share a common ground in terms of claiming the truth:

Historiographic metafiction refutes the natural or common-sense methods of distinguishing between historical fact and fiction. It refuses the view that only history has a truth claim, both by questioning the ground of that claim in historiography and by asserting that both history and fiction are discourses, human constructs, signifying systems, and both derive their major claim to truth from that identity. (Hutcheon, 1981, p. 93)

Stressing that both history and fiction are discourses, in historiographic metafiction, history is considered equivalent to a fictional work. Similarly, Hayden White, who is one of the leading figures of the postmodern philosophy of history, avers:

Historical narratives are verbal fictions, the contents of which are much invented as found and the forms of which have more in common with their counterparts in literature than they have with those in science. (1978, p. 82).

Rather than being scientific, history is, according to White, much closer to art. In this regard, postmodernism highlights the similarity between history and literature. In this respect, to foreground the similar construction of truth in historical accounts and fiction, in historiographic metafiction the line between fact and fiction is opaque to such an extent that history becomes fiction and fiction becomes history. As thus envisioned, the old distinction between history and fiction is removed, and the discourses of the fictional and the factual intermingle to foreground the constructedness of both genres.

One of the most apparent ways of problematizing the distinction between historical fact and fiction is the existence of historical figures in The White Hotel. The most significant instance of this is Sigmund Freud and his case history, but the presence of historical figures is not in accordance with official history. If this novel had been written in the mode of the traditional historical novel, the role played by Freud would have been consistent with the actual Freud, or it would have been consistent with historical documents. However, as D. M. Thomas

\footnotetext{
$\dagger$ Sandor Ferenczi (7 July 1873, Miskolc - 22 May 1933, Budapest) was a Hungarian psychoanalyst, a significant figure of the psychoanalytic school, and a friend of Sigmund Freud.

* Hanns Sachs (10 January 1881, Vienna - 10 January 1947, Boston) was one of the earliest psychoanalysts and a close personal friend of Sigmund Freud.

$\S$ Kuhn is represented as the secretary of Goethe Centenary Committee in 1931 in Frankfurt, but there is not any information whether there is really a historical figure named Kuhn or not. So Kuhn may be an entirely fictional character.

** Frau Anna G. is the name used by Freud for Lisa Erdman.
} 
self-consciously states in the "Author's Note," in The White Hotel the figure of Freud includes fictional (untrue) elements: "The role played by Freud in this narrative is entirely fictional. My imagined Freud does, however, abide by the generally known facts of the real Freud's life, and I have sometimes quoted from his works and letters, passim" (p. vii). Although Freud in this novel is consistent with the actual Freud to a certain extent, the historical figure Freud did not have any patient called Anna G . and he did not produce her case history. Hence, Anna G. never existed historically. On the other hand, although Thomas claims that Freud, the letters, and the case history "[have] no factual basis" (1981, p. vii), there are still many similarities with the actual life story of Freud and historical documents. The reader is not able to make a clear-cut distinction between two seemingly separate ways of knowledge. So the reality status of the information cannot easily be granted. ${ }^{\dagger \dagger}$

Another obvious instance of mixing reality with fiction shows itself in the way footnotes are used. Conventionally, footnotes are not expected to be used in creative writing; this is rather a practice of traditional historiography. However, while Freud presents Frau Anna G.'s personal history, there are some footnotes used to give extra information about the text. The existence of the footnotes immediately creates the impression in the reader's mind that these are factual writings by Freud. The reader also realizes that these are partly fictional because the historical Freud did not have such a case history. In this way, the boundary between fact and fiction is blurred. As Hutcheon argues, the use of footnotes in historiographic metafiction serves to "undermine the authority and objectivity of historical sources and explanations" (1988, p. 123). The existence of an unknown translator or editor in the novel complicates things further. The footnotes given in brackets refer to the translator's comments on the text. For example, "[In the text there is a play on the word niederkommen, which means both 'to fall' and 'to be delivered of a child.']" (Thomas, 1981, p. 102). The implication creates an atmosphere suggesting that "Frau Anna G." is originally written in German and then translated, and that it really belongs to the historical figure Sigmund Freud, which enhances the reality status of the case history. Although the case history is a fictional product of D. M. Thomas, the mixed footnotes invoke the perception that the case history is really written by the historical Sigmund Freud; therefore, this implication disturbs the traditional distinction between fact and fiction by subverting a convention of traditional historiography.

One of the arguments put forward in Hutcheon's A Poetics of Postmodernism is that postmodernism attempts to emphasize that the past is only known via texts which are human constructs. Contrary to the truth-claims of traditional mainstream historians in representing the past as it actually was, postmodern history writers are of the opinion that the past is a construct since the past appears only as text.

In arguing that history does not exist except as text, it does not stupidly and "gleefully" deny that the past existed, but only that its accessibility to us now is entirely conditioned by textuality. We cannot know the past except through its texts: its documents, its evidence, even its eye-witness accounts are texts. Even the institutions of the past, its social structures and practices, could be seen, in one sense, as social texts. (Hutcheon, 1988, p. 16)

Historiographic metafiction emphasizes the textual nature of historical works and its reference points as documents, evidence, eye-witness accounts etc. The evidence, which is assumed to be the most significant element that distinguishes history from fiction, is treated as text. A consideration of the textuality of everything in postmodern historiography leads in turn to questions of reference. Traditional understanding of reference is that "what history refers to is the actual, real world; what fiction refers to is a fictive universe" (Hutcheon, 1988, p. 142). In

\footnotetext{
it The detailed analysis of to what extent the fictional Freud resembles the historical Freud will be made later when intertextuality is discussed. However, that the fictional Freud is also a psychoanalyst may suffice to make the argument that Thomas's Freud resembles the actual Freud.
} 
historiographic metafiction, instead of referring to the observable and physical reality, supposedly historical facts or figures are solely textual products and the only reference they can make is to other texts. Thus, the vaunted status of evidence strengthening the illusion of reality in traditional historiography is shattered in historiographic metafiction.

The self-reflexively intertextual nature of The White Hotel is another metafictional strategy that enhances the novel's relation to historiographic metafiction. Of course, traditional historical fiction is also intertextual because it relies on other texts, such as historical documents, interviews, and historical artefacts. However, traditional historical fiction conceals this fact. By contrast, The White Hotel emphasizes the intertextual aspect of historical fiction. The novel overtly makes use of other texts mainly from two major areas: Freud and his psychoanalysis, and the Holocaust. The composition of both Freud and his approach in the chapter, "Frau Anna G.," depends to a certain extent on the actual Freud's life and psychoanalytic practices. "Frau Anna G." represents the case history of Anna who has a psychological disorder. It tells how Freud tries to treat Anna by digging her past, including the therapy sessions and interviews. The two texts used by the actual Freud in this chapter are Beyond the Pleasure Principle and From the History of an Infantile Neurosis (the case history of the Wolf man). The letters, Freud's case study, historical events, and people have a factual basis to a certain extent contrary to what is claimed in the author's note that it "has no factual basis" (Thomas, 1981, p. vii). Yet, that these texts are fictional is also true, for they also contain imaginary sections that are not found in the actual documents. Thus, they both have fictional and factual aspects.

The first letter in "The Prologue," for example, exists as a historical document. Ferenczi writes a letter to Gisela (Palos), the USA for a conference. ${ }^{\S \S}$ Thomas, however, adds a fictional paragraph for the purpose of blurring the line between fact and fiction.

But you will want to hear about the voyage ... Jung especially was gripped by the conception of this "prehistoric monster" wallowing through the daylight-darkness towards its objective, and felt we were slipping back into the primeval past ... (Thomas, 1981, p. 4)

The letter in the novel carries the same date and place (8 September 1909, Massachusetts) but the paragraph quoted above has been added for the author's own purposes. Moreover, some of the characteristics of Anna are borrowed from historical figures although Anna is a fictional character. During the therapy sessions, Anna goes on holiday at Bad Gastein where she produces her lyrical pornographic poem when she was "in a fever of physical desire" (Thomas, 1981, p. 183). ${ }^{* * *}$ Similarly, in "the case of Fraulein Elizabeth von R.," the actual Freud recommends his patient, Elizabeth von R., to take a course of hydrotherapic treatment at Gastein due to her pains in the legs, where the patient's erotic feelings, as well as her pains, reach their full height (Swinden, 1982, p. 76). Fraulein Elizabeth von R.'s experience is quite similar to Frau Anna G.'s experience. "The Wolf Man's case" is another instance of resemblance; although Freud originally claims that he has cured his patient who had the pseudonym the wolf man, later it appears that he has not cured him totally (Lougy, 1991, p. 95). Just like the historical Freud, in the novel, Freud is not able to cure Lisa fully as a result of therapy. Furthermore, D. M. Thomas states that while he was reading Ernest Jones' biography of Freud, he encountered that one of Freud's patients claimed, as in the chapters "Don Giovanni" and "The Gastein Journal," that she had an affair with Freud's son (Thomas, 1983, p. 1958). Another example is the historical Freud's analysis of "Dora's case." In Dora's case Freud treats bodily

\footnotetext{
\# Gisela Palos is "Ferenczi's mistress" (Kahn, 1996).

$\S \S$ The real letter can be found in D. M. Thomas's article entitled Freud and The White Hotel.

*** Freud tells Anna to write down her impression after she has come from Bad Gastein. In the next chapter, the reader learns that Anna has hidden the fact that she produced the poem at Bad Gastein.
} 
pain as a symbolic representation of a problem in the past. Dora suffers from a limp which has no apparent organic cause, and Freud diagnoses the limp as a metaphor representing a false step that Dora took in her past (Vice, 2010, p. 45). Dora's situation reminds one of a similar Freudian approach to Lisa's case. A clear example is that according to Freud, Lisa develops bodily pains as a conclusion of her repression of undesired urges such as homosexuality:

The incompatible idea had to be suppressed, at whatever price; and the price was an hysteria. The symptoms were, as always with the unconscious, appropriate: the pains in the breast and ovary because of her unconscious hatred of her distorted femininity. (Thomas, 1981, p. 140)

The same approach, therefore, is used in Anna's case in which the fictional Freud relates her pains to her homosexual urges. Therefore, "Frau Anna G." contains factual or historical details in its fictional universe. The reader always feels lost to what extent s/he is reading fact or fiction. In this regard, the division between fact and fiction is opaque.

Other texts that foreground the intertextual nature of The White Hotel are about the Holocaust. In "The Sleeping Carriage" chapter of the novel, Lisa's murder, written in the realistic mode, depends largely on Anatoli Kuznetsov's documentary novel Babi Yar, which is about the Babi Yar massacre that took place in 1941. ${ }^{\dagger \dagger \dagger}$ The Babi Yar massacre occurred after the German troops occupied Kiev, the capital city of Ukraine. More than 30,000 Jews were murdered in three days, and by the time the Germans had retreated from Kiev, the number killed at the Babi Yar ravine was more than 100,000, including gypsies, communists, and Russian prisoners of war (Quinn, 2004, p. 37). In Babi Yar, Kuznetsov documents down what he saw at Babi Yar as a 12-year-old witness of the massacre. In The White Hotel, the events in the Podol (where Lisa and her stepson Kolya live) and the way Jews are killed and they are thrown into the pit depend on Kuznetsov's novel. Not only do most of the historical events depicted in "The Sleeping Carriage" depend on this documentary novel but also the characters in the novel have some affinities with historical figures, such as Dina Pornicheva and Tolya Semerik who are two of the few survivors of the Babi Yar massacre. Lisa, for example, shares some of the characteristics that Dina Pornicheva has. Dina is an actress in the Kiev Puppet Theatre; Lisa, who was born in Kiev, has been a dancer and an opera singer. Both women are Jewish, but neither is particularly Jewish in appearance and both have non-Jewish surnames (Brown, 1985, p. 67). Lisa also shares some of the characteristics of Tolya Semerik's grandmother. Tolya Semerik's grandmother has the ability to foresee the future, which is similar to Lisa's abilities of clairvoyance:

"[T]he time will come, a terrible time, when the enemy will swarm across the country and all the land will be covered with barbed wire, and there will be metal birds flying in the sky who will peck people with their iron beaks, and that will be just before the end of the world ..." ... Everything has turned out as Granny foretold - the wire and the iron birds, and I suppose we shall soon see the end of the world. (Kuznetsov, 1970, p. 29)

The grandmother's premonition about the end of the world comes true in Babi Yar. Similarly, in The White Hotel, Lisa foresees the deaths of many and herself in Babi Yar in a symbolic way just as Semerik's grandmother does. In "The Gastein Journal," in which her absurd looking fantasies and hallucinations are narrated, some events significantly resemble the events in the massacre. The narrator, for example, tells how the guests in "the White Hotel" fall into the pit during a funeral service: "The young woman [Anna/Lisa] saw the mourners fall one by one, into the trench, as if intolerable grief afflicted them, one by one" (Thomas, 1981, p. 72). As in the grandmother's account, in which metal birds are associated with war crafts in the Second World War, in Lisa's journal, falling mourners refer to the people who are thrown into the pit in Babi Yar in 1941. Tolya Semerik, too, bears similarities with Motya in The White Hotel.

\footnotetext{
${ }^{\dagger \dagger}$ Babi Yar in censored form was originally published in Russia in 1966. The uncersored version was published in 1970 in the UK.
} 
Tolya Semerik is the boy who escapes from the ravine with Dina Pornicheva in Babi Yar. Like Motya in The White Hotel, Tolya tells Dina: "Don't be frightened lady! I'm alive, too" (Thomas, 1981, p. 250; Kuznetsov, 1970, p. 85).

Thus The White Hotel sometimes overtly and sometimes covertly makes use of other historical and fictional texts, hence blurring the boundary between fact and fiction. It is not just that the events are similar to other texts; it is also the properties of many characters that share some common points with historical figures. D. M. Thomas composes a fictional work by using historical events and figures. The deployment of other texts has led to a lot of criticism against The White Hotel. Many critics repudiate this novel as it has been either explicitly or implicitly composed by depending largely on other texts ranging from Freud's case studies to Holocaust documents. If an example is to be given to summarize the charges (not to mention the charges of plagiarism), Martin Amis's criticism could be discussed regarding the novel's employment of the eyewitness account of Anatoli Kuznetsov in "The Sleeping Carriage." The novelist Martin Amis condemns D. M. Thomas, for Thomas, in The White Hotel, excessively uses the same dramatic events and figures in the same manner as in Babi Yar. He harshly claims that "the testimony is unbearably powerful; it is the climax of the novel; it is, in plain terms, the best bit - and Thomas didn't write it [himself]" (Amis, 2002, p. 142). Amis accuses Thomas of lacking the ability to create his own original piece about the Babi Yar scene in "The Sleeping Carriage," which is, according to Amis, the most powerful looking section of the novel. However, Amis seems to ignore the rest of the novel and the meaning emerging from the whole novel. Confining the intertextual nature of the novel only to the discussion of plagiarism, or to the discussion of the writer's ability/inability in this novel, would be a shallow misreading. Ignoring how the novel questions the reality status of the representation of any event in the Holocaust would be trivializing the magnitude of the subject and reducing it to a shallow platform. This, at the same time, would be doing injustice to the writer and to the novel. A worthwhile attempt, instead, would be to discuss the reason why the author uses these texts and to try to understand the implications of this practice. This would make a better contribution to the literary criticism of the novel. By using these techniques, for example, the novel may selfreflexively be trying to highlight that any account is a text and hence a construct with a high potential of unreliability. Therefore, the novel's employment of many other texts can be seen as a way of emphasizing the intertextual nature of all historical accounts, which were traditionally assumed as original and representing the truth.

Linda Hutcheon presents another important aspect of historiographic metafiction as the problematization of Cartesian subjectivism. The subject (historian, narrator, character, or implied author), conventionally thought, was a unified, self-sufficient, and coherent being who could observe the empirical world and produce objective knowledge by rationally interpreting them. The historian plays the role of a scientist by searching the eye-witness accounts, artifacts, governmental documents, etc. concerning an event that happened in the past from an objective perspective, which White calls "the innocent eye" (1978, p. 53). The historian has an unshakable confidence in producing and representing her/his knowledge about the past. In a similar way, the historian approaches historical figures as unified subjects that can be clearly analysed and understood. This is similar in traditional historical fiction too: The historical characters are portrayed rationally, and there is not any inconsistency or uncertainty in the formation of the subject. By contrast, in historiographic metafiction, the subject seems dethroned from its old place. Hutcheon designates two ways of creating this problematization in novels: "multiple points of view" or "resolutely provisional and limited" point of view (1988, p. 11). In both approaches the subject is never sure about the past. The readers are left on a shaky ground where they are never certain about the truth of the past. In both of them, subjectivity is challenged against the totalizing approach of traditional historians/narrators. In 
contrast to the traditional historian/narrator whose function is to represent historical account as the truth, most of the time the narrator is unreliable and fragmented in historiographic metafictional novels. For instance, in Salman Rushdie's Midnight's Children (1981), the protagonist, Saleem Sinai is so fragmented a character that his body, like the history of India of the time, falls apart towards the end of the novel (Hutcheon, 1988, p. 118). This fragmentation creates narrative holes that need clarification by the reader, and this leads in return to the comprehension of the narrator and narrative as a human construct. In addition to this, the illusion of reality created by the authority of the traditional historian and the novelist is broken through the problematization of subjectivity.

The White Hotel, too, problematizes the Cartesian understanding of the subject in historiography by employing a protagonist (Lisa) who is almost impossible to define because she lacks unity and a stable vision about herself. ${ }^{+1}$ The protagonist's religious identity is complicated, and this functions as a means of preventing her from building a stable identity. Her mother is a Polish Catholic, while her father is a Russian Jew. Yet, she does not admit her Jewish identity until the very end when she realizes that there is no escaping the murder in Babi Yar (Thomas, 1981, p. 239). The name of the protagonist can be accepted as an indicator of her unstable identity, too. In traditional historical narrative, the identity of historical figures is introduced at the beginning, and it is never problematized. In The White Hotel, however, until Freud's case history, the reader does not know the real name of the protagonist. In Freud's case history the reader first comes across her name as Anna G. (Thomas, 1981, p. 90). ${ }^{\S \S}$ The real name, Frau Elizabeth (Lisa) Erdman, is introduced in "The Health Resort," in which Lisa's life after Freud's treatment is narrated (Thomas, 1981, p. 147). After she is married to Victor Berenstein, who is a Russian Jew, she gets his surname. When Lisa is asked her name at the beginning of the final chapter "The Camp," she hesitates in giving her name. Is it Berenstein (her husband's), Erdman (her German name), Morozova (her maiden name), or Kanopnicka (her mother's maiden name)? (Thomas, 1981, p. 258). Thus Lisa has so many names that she is not sure which one defines her. This is yet another indication of how Lisa does not have a stable identity. As Hutcheon states, "Surely The White Hotel is . . about the impossibility of a 'fixed subject-vision,' about the 'uncertainty of vision"” (1986, p. 79).

"What 'engenders' Lisa is a series of discourses," says Hutcheon (1988, p. 171). In each chapter the protagonist's subjectivity is reformulated. Once the reader constructs a stable identity for Lisa, it is immediately deconstructed. Linda Hutcheon describes Lisa's subjectivity as follows:

The female protagonist is not fully or consistently a traditional Jamesian center of consciousness with whom the reader can identify as subject. Nor does she seem to be the reflection of any authorial subjectivity upon which she might be based. Instead, she is presented as the "read" subject of her own and of others' interpretations and inscriptions of her. She is literally the female product of reading. (Hutcheon, 1986, p. 80)

In "The Prologue," Lisa is constructed by the letters between psychoanalysts. Later, the details of her character are given through her pornographic poem and its extended prose version. In the following chapter, she is formulated through a psychoanalytic perspective by Freud. In the next chapter, "The Health Resort," the character is given other dimensions from an unknown third-person's perspective. Following this, in "The Sleeping Carriage," Lisa's life is narrated by a distant narrator. As it is explained by Hutcheon, "she [Lisa] is presented as the read subject

\footnotetext{
+* In this novel, history writing is treated in two distinct but related ways. The first is the construction of the individual history of Lisa Erdman through a variety of means, and the second is the representation of the Holocaust, which is also an event that terminates Lisa's personal history.

$\S \S \S$ This is the pseudonym given by Freud to "protect" the patient's identity.
} 
of her own and of other's" (1988, p. 161). As Vieira emphasizes, the subject is never "composed":

\begin{abstract}
But to say that the subject is "composed" through these discourses is not accurate. Better to say that the subject is decomposed or deconstructed because we never get at whatever it is that constitutes Lisa Erdman. Rather than adding to a coherent self, these chapters undermine previous compositions of the self; not only do we find that we have not known the whole truth, but we discover that we have been fooled by our preconceived judgments and have grossly misinterpreted the subject; I am thinking of Freud's, and I might add our, tendency to read Lisa's telepathy as revealing her past, rather than prophesying her future. (Vieira, 1993, p. 122-23)
\end{abstract}

Through Freud's reading of Lisa's past, the reader is allowed to formulate a fixed subjectivity, and s/he thinks that the patient definitely has a psychological disorder which has its roots in her childhood, but events suggesting close links with Lisa's symptoms occur in her future. Freud tries to fix her identity, but in the end of the novel, it is suggested that Freud may have been wrong in the first place because he related her situation to her past and to "severe sexual hysteria" (Thomas, 1981, p. 11). At the end of the novel, however, the reader has received the impression that Lisa's symptoms were primarily related not to her past but to her future, when she would suffer severe injuries in the Babi Yar massacre. In that sense, the second part of the novel falsifies, to a certain extent, the first part including Freud's reading of Lisa's past.

Lisa herself cannot construct a stable subject vision either. She is not able to form a fixed perspective about the events around herself, contrary to the traditional understanding of the subject who can observe the empirical world and produce consistent knowledge. In the chapter "The Sleeping Carriage," Lisa does not understand that she is going to die until the last minute. The narrator even portrays a German soldier and a Ukrainian policeman from Lisa's perspective as if she felt sympathy for the soldiers who would soon be responsible for her death: "It was hard not to admire his striking looks and air of authority; and equally hard not to feel, now, a grain of sympathy for the soldiers and police who were having to control the swearing, bad-tempered crowd" (Thomas, 1981, p. 237). Apart from that, Lisa has many forgotten memories which are thought to be crucial elements that form her. These forgotten memories are brought to the surface and a past is constructed for Lisa with the help of Freud. However, there are serious gaps here as well. Lisa sometimes deliberately subverts the events in her past for various reasons. After having read the case study and believed in the truth of the information provided there, the reader is surprised to read much later in "The Health Resort" chapter that much of the information provided in the case history was wrong simply because Lisa lied to Freud about certain of her experiences or had preferred not to refer to some of them. In a correction letter to Freud, for example, she confesses not having told him about a traumatic sexual event in her childhood, which might have been crucial in Freud's study of her:

$[\mathrm{T}]$ here are other deceptions which were, and I've decided I ought to tell you [Freud] about them, for you may feel that your case study needs changing - or even abandoning. I shan't blame you if you hate me for all the lies and half-truths I told. ... On one occasion in my childhood I wandered onto Father's yacht when I wasn't supposed to, and I found my mother, and my aunt and uncle, there all together, naked. It was such a shock, I thought I was seeing my mother's (or perhaps my aunt's) face reflected in a mirror; but no, they were both there. (Thomas, 1981, p. 184)

This and similar revisions in the novel continually disorientate the reader, making her/him unable to put the parts together to form a meaningful whole. Since Lisa, as a character, is not a reliable personality or consistent subject, how can a traditional narrator/historian represent her as a stable subject? The White Hotel, therefore, "can be seen as a novel that overtly challenges both the realist novel's representation of the world of consistent subjects who can offer an origin of meaning and action and also its presentation of a reader position from which the text is easily understandable" (Hutcheon, 1988, p. 169). Thus, the novel questions the understanding of the traditional subject in historiography and historical fiction. 
Another important characteristic of historiographic metafiction, which is closely related to the problematization of traditional notions of history writing such as objectivity or neutrality, is self-consciousness/self-reflexivity of the text, which means the "theoretical self-awareness of history and fiction as human constructs" (Hutcheon, 1988, p. 5). In traditional historical writings, the role of the historian is supposed to be one of the most important elements in the constitution of reality. S/he is assumed to be the sole authority over the account. The historian constructs the account in a way that one does not need to question the reality status of what is given. However, in historiographic metafiction, the implied author is fully aware that what $\mathrm{s} / \mathrm{he}$ produces is a human construct, and deliberately emphasizes this feature which indirectly undermines the authority of the historian. The narrator in the historiographic metafictional novel is one of the elements that shows the self-consciousness of the text. The narrator systematically draws attention to the work's status as a construct. As Kurca rightly puts it: "The presence of a self-conscious narrator who points to the rhetorical devices constructing the text is a means of breaking the illusion of reality" (Kirca, 2009, p. 14). In practice, the narrator in historiographic metafiction explicitly discloses the writing processes (e.g. by making comments on what s/he writes) to show that reality is a construct. The self-reflexivity of these novels allows the reader to gain critical insight or "incredulity" towards what is represented in the novel itself. To put this in Waugh's terms, self-consciousness helps the reader to "explore the possible fictionality of the world outside the literary fictional text" $(1984$, p. 2). In this way, the critical insight leads the reader to revise her/his early readings about history in terms of the representation of reality and to question the legitimacy of what is given as the truth. Serpil Oppermann explains the function of self-conscious writing as follows:

In historiographic metafictional novels, the way history is presented draws attention to how historical facts are created. In this way, the basis of empirical epistemology is destroyed as a whole. Consequently, the plausibility of the truths that traditional realist theory uses as criteria becomes debatable as well. (Oppermann, 2006, p. 52; my translation)

The significance of this proposition is that the emphasis on the metafictive nature of postmodern historical fiction creates an opportunity for questioning or rethinking the claims of truth in traditional historical writing or all writing. The self-consciousness/self-reflexivity of historiographic metafictional novels may have its effect on many aspects of the narrative. The traditional employment of narrative structure, causal relationship, and linear time-sequence in both historical accounts and historical novels are vigorously contested in historiographic metafiction by referring to their construction process. For instance, one of the ways this is done is through narrative discontinuity. The author intrudes into the narrative and makes comments. ${ }^{* * * *}$ Waugh contends that "through continuous narrative intrusion, the reader is reminded that not only do characters verbally construct their own realities; they are themselves verbal constructions, words not beings" $(1984$, p. 26). The centrality of language in the constitution of meaning and reality is therefore more specifically emphasized through selfreflexivity. Similarly, the nineteenth-century narrative continuity is threatened by problematizing the narrative closure (death, marriage; neat closure) to foreground how writers and readers construct endings as in Fowles's The French Lieutenant's Woman (1969), where multiple endings - three different ones - are employed (Hutcheon, 1988, p. 59). This openness and flexibility in narrative closure destroy causal relationships and linearity at the same time. The reader cannot steady her/himself for any fixed perspective to identify the causes of what

\footnotetext{
**** This convention was already present in the nineteenth-century realist novel, but it is not an example of metafiction. Instead, "it functions mainly," as Waugh mentions, "to aid the readerly concretization of the world of the book by forming a bridge between the historical and the fictional worlds" (1984, p. 32). In other words, the fictional and the factual are complimentary in nineteenth-century realist novels. However, what metafictional novels do is to foreground the "ontological distinctness of the real and fictional world" (Waugh, 1984, p. 32).
} 
comes later. Thus, the rational narrative structure of the traditional way of history writing is problematized by making the reader focus on the techniques employed.

The multiplicity of literary forms/styles is another characteristic of The White Hotel that makes it historiographic metafiction. D. M. Thomas constructs each chapter in a different literary form and style. Using, respectively, epistolary narrative, poem, prose, case history, traditional realism, documentary realism, and allegoric vision, the reader is left in a shaky ground in terms of making sense of the events narrated and their relation to historical reality. Each different form and style has a certain function through which the reader is directed to a certain interpretation of the events. "Genre," as Robert Eaglestone writes, "is not a just way of writing: it is simultaneously a way of reading, too" $(2004$, p. 6). Thus each chapter implies to the reader what s/he will read and how s/he will read it. What is more, in each subsequent chapter, there are some extensions, revisions, and modifications of earlier chapters. It would not be wrong to suggest that the whole novel is built on constructing a reality and deconstructing that reality.

The epistolary form in "The Prologue" creates the impression that the patient has definitely some problems with her past. The patient's poem, the product of her imagination, has many sexual, symbolic details and catastrophic details, and it encourages a reading of the patient's past from a psychoanalytic perspective.

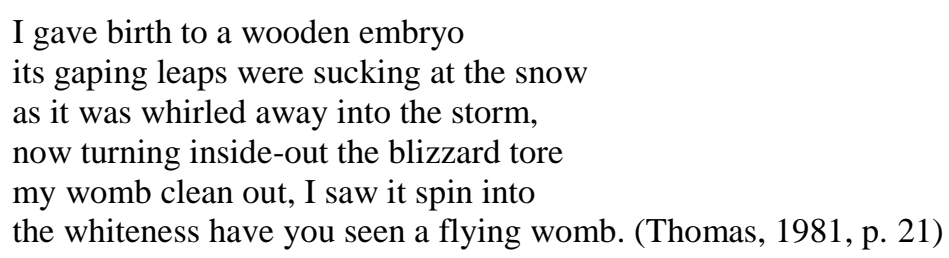

The persona gives birth to "a wooden embryo," her "womb" is cleaned, and the embryo flies. As it is previously evoked that the patient is ill (Thomas, 1981, p. 11), the reader thinks that her writings have "symbolic meaning" which has its ground in the protagonist's childhood. Once the reader is engaged with the poem, s/he immediately establishes the relationship with the patient's damaged psychology and the necessity of a Freudian approach, which has previously (via letters) been evoked in the reader's mind. Following this chapter, the reader is introduced with the prose version of the same poem. "The poem and the journal with its intense sexual imagery cry out for a Freudian interpretation" (Tanner, 1991, p. 139). The following chapter then gives the analysis of the patient in the form of Freud's case history. At the end of "Frau Anna G.," the reader has a firm belief that the illness of the patient stems from her childhood experiences and that the patient is almost cured. Thanks to Freud's help, the patient's repressed memory has come to the surface, and Freud has made her encounter with her past possible, and recovery is mostly achieved.

In "The Sleeping Carriage," however, the protagonist's life after Freud's treatment is introduced to the reader in the mode of realism. The reader is inclined to believe the events in this chapter are representing the truth about Lisa since the events are described in a realistic setting and mode. For instance, in Lisa's poem, there is a fire in the hotel (Thomas, 1981, p. 20 ), and the reader treats it as Lisa's imaginative product. Freud then relates this detail to an incident in Lisa's childhood: Lisa learns that her mother has died as a result of "a fire that destroyed the hotel in which she [Lisa's mother] was staying" (Thomas, 1981, p. 93). However, later in the novel, in "The Sleeping Carriage," another hotel fire incident appears again during Lisa's adult years. Occupied by the German troops, the luxurious flats of Kreshcatik in Kiev, which can be related to the "white hotel" in her poem, are exploded by the Russians (Thomas, 1981, p. 233). Although the events are referred back to the patient's past in Freud's case history, similar events are realistically portrayed in Lisa's future in "The Sleeping Carriage." As a result, 
Freud's whole analysis and way of looking at the protagonist's life is demolished and replaced by other constructions. The reader is left in a difficult position, being unable to decide which version is correct. The novel never provides the reader with any firm belief about the actual past (if there is any). The novel plays with forms to leave the reader on a fluid floor. There are always questions on the reader's mind about the truth status of Lisa's past:

Its multiple and often contradictory forms and points of view (first-person poem, third-person expansion of it in prose, "Freudian" case history, third- person limited narration, first-person epistolary form used by many characters) call attention to the impossibility of a totalizing narrative structure. (Hutcheon, 1986, p. 83)

Although different chapters are written in different genres and literary forms, all of them share similar qualities in terms of reflecting the truth. In each different mode, the expectation of the reader is confounded as to who Lisa is and whether she really foresees the future or not. There is not any hierarchical order between these modes in terms of truth in the past since neither genre nor form leads the reader to a firm conclusion about Lisa's life. The novel does not provide a stable way of reading. As a result of an overt play with genres and forms, the reader cannot construct a stable interpretation about Lisa's past. So, if it is seen from the representation of the history of a person, the suggestion is that one can never have a fully reliable construct.

Multiple narrators and points of view are other aspects of The White Hotel that separate it from traditional historical fiction. The traditional historical fiction writer usually employs an omniscient third-person narrator to compound the reality effect. However, in The White Hotel, the multiplicity of narrators and perspectives is one of the reasons of not reaching a stable and monolithic conclusion about the novel, and this strengthens the novel's ambivalent atmosphere concerning the truth about the patient's past. "The narrative unity within each section of the novel is disrupted by the start of another section with a different point of view" (Hutcheon, 1986, p. 84). Freud's letters to Ferenczi and to Herr Kuhn in "The Prologue," although limited, give insights into Lisa Erdman's case. Lisa's poem in the first person and journal in the thirdperson are written by the patient herself. Then Freud's account of the protagonist life in the form of a case history is introduced, and the reader constructs the patient's past. The remaining three chapters - "The Health Resort," "The Sleeping Carriage," and "The Camp" - are thirdperson narratives. In these third-person narratives, however, the point of view does not always belong to Lisa. Although in "The Sleeping Carriage" Lisa is generally the focalizer, it starts with her stepson's perspective abruptly, and then the focalization passes to Lisa again. A similar construction is also present at the end of the chapter. After Lisa and Kolya are thrown into the pit, the events are interestingly narrated from another's perspective, which belongs to Dina Pronicheva, one of the few survivors of the massacre:

An SS man bent over an old woman on her side, having seen a glint of something bright. His [a soldier] hand brushed her breast when he reached for the crucifix to pull it free, and he must have sensed a flicker of life. Letting go the crucifix he stood up. He drew his leg back and sent his jackboot crashing her left breast. (Thomas, 1981, p. 248)

The "old woman" who is crushed by the soldier is Lisa, and "her" refers to Dina Pronicheva. Lisa has been the focalizer up to the point when she is murdered in Babi Yar. In this quotation, Dina is the focalizer. The multiplicity of narrators and perspectives puts the reader in a difficult position to build a coherent perspective about the historical event. This characteristic of the novel also undermines the role of the traditional historian which is to construct a clear, consistent, and meaningful account.

The unconventional chronology and plot structure of The White Hotel also contribute greatly to the novel's status as historiographic metafiction. In traditional narratives, time flows forward and is linear. The events follow such a pattern that an event leads to another event successively, and therefore the causal connections are easily established. Contrary to linear 
succession of the events in forward elapsing time sequence in traditional history writing, in The White Hotel, the events do not follow a coherent structure. There are letters at the beginning of the novel, but it is not clear why they are there. The first letter is written in 1909, and the last is written in 1931. Although most of the events in the novel take place before 1931, the last letter appears first. There is a poem and a prose version of it, but no one knows when they are written, what purpose they serve, or why they are written. The questions are answered much later by Freud in the chapter "Frau Anna G.." The reader is informed that the psychoanalyst has asked his patient to write down her impressions of her holiday at Bad Gastein (Thomas, 1981, p. 113). Although Freud has asked this after he has started examining Lisa, the poem and the journal appear first. In conventional fiction, the narrative would instead start with Freud's case history. Thus, the time sequence is so chaotic that there is not any coherence between the chapters.

The arbitrary narrative closure in The White Hotel is another component of historiographic metafiction that questions the neat narrative closure in traditional historical fiction. In traditional historical fiction, closure is neatly drawn because all the events that have been narrated before serve the closure. At the same time, the closure gives legitimacy to the previous events. If there is a proper closure in the narrative, then all the questions are answered and the order is established. It may be the order itself (or the illusion of the order) that makes people believe a historical construction. However, the closure - the final chapter titled "The Camp" - in The White Hotel does not fit this traditional understanding. In the previous chapter, it has been narrated that Lisa, as a Holocaust victim, was bestially murdered in the Babi Yar ravine in 1941. Although the portrayal of the massacre is quite realistic, in "The Camp," Lisa, strangely, comes back to life in another realm. This kind of ending is, in its simplest meaning, a completely unsuitable ending for any conventional narrative and hence for traditional historical fiction since they are highly concerned with representing the truth about the past. Because no one can come back to life again in reality, this ending is traditionally not suitable. In that sense, this section is "the perfect anti-closure" as Hutcheon calls it (1988, p. 176).

Another reason that makes "The Camp" contradict traditional closure is its uncertainty. "The Camp" simultaneously consists of two distinct discourses: fantastic and historical. It is fantastical because it is a portrayal of an afterlife; it is historical because it looks like a depiction of Israel. The simultaneous presence of two different discourses can be seen in the opening of this final chapter. The first paragraph of the chapter is like a continuation of the previous chapter in which the Jews believed that they were sent to Palestine by train instead of being massacred in Babi Yar. ${ }^{\dagger \dagger \dagger \dagger}$

After the chaos and overcrowding of the nightmarish journey, they spilled out on to the small, dusty platform in the middle of nowhere. They struggled over a little bridge; then it was good to breathe the sweet air, and to be ushered through without bullying or formalities. Outside, there was a line of buses waiting. (Thomas, 1981, p. 257)

Just as the Nazis promised them in "The Sleeping Carriage," they arrive at Palestine after "the chaos" of Babi Yar. The reader is provided with some places where Lisa and other characters stay, namely, Cana (Thomas, 1981, p. 266), Emmaus (p. 262-264), Dead Sea (p. 272), and the mountains of Bether (p. 264). Although these actual places are allusions to the Bible, there are studies that associate these places with some locations in Israel and Lebanon.

However, that the characters come back to life adds a fantastic element to this realistic representation. Lisa reunites with all of her family members, Freud and his daughters, her friend Luiba Shchadenko and her children, Kolya's mother Vera, Ludmila Kedrova, her friend in

\footnotetext{
$+1 \dagger$ Lisa and many others who were sent to death in Babi Yar thought that they were leaving for "Palestine" (Thomas, 1981, p. 232).

\$+ Additional information about these places can be obtained from Catholic Encyclopedia website.
} 
Petersburg etc. In a sense, it is also close to the portrayal of afterlife where characters meet and problematic aspects in life are getting better. The two different discourses, reality and fantasy, come together in this chapter. Linda Hutcheon claims that this chapter foregrounds the arbitrariness of closure, which is also a characteristic of historiographic metafiction:

All the narrative ends are tied up: characters meet and sort out their difficulties (even the abandoned cat reappears). Yet it is fundamentally inexplicable by normal narrative logic, and its time (after Lisa's death?) and place (Israel?) cannot be fixed with any certainty. What this ending does is foreground the arbitrariness of traditional novelistic closure, while nevertheless allowing, even demanding, it. (Hutcheon, 1988, p. 176)

There is an ambiguity because realistic and fantastic elements are processed simultaneously. The characters still bear the traces of the wounds that they have in their previous life. Freud "attempt[s] to eat" food with his "heavily bandaged jaw" (Thomas, 1981, p. 260). Lisa's mother has "dead skin" on her left side from face to foot (Thomas, 1981, p. 266). Thus, it is neither a perfect portrayal of an afterlife nor a portrayal of real life; it is neither heaven nor Palestine but a mixture of them. Contrary to its practice in traditional history writing where closure reinforces moral values with its monolithic structure, it is quite possible to claim that the final chapter here provides the reader with multiple endings or uncertainty where the reader can adopt any approach. It could also be argued that this kind of ending disturbs the understanding of linearity and the assertion of moral values expected of a traditional historical narrative. It is hard to observe any emancipatory situation in this ending because it stands inconsistent with, and independent of, the previous sections. It does not offer any monolithic approach because it is ambivalent. Therefore, it is against a monolithic perspective in its celebration of multiplicity and ambiguity.

In the light of the above discussion about the employment of experimental techniques, it has been argued that The White Hotel is a powerful example of historiographic metafiction. In The White Hotel, the boundary between historical fact and fiction is so opaque that the reader has difficulty in making this distinction; also, the way of constructing factual and fictitious details foregrounds the parallelism of both. Freud's case history of Lisa enhances the metafictional effect because the case history can be read as a suitable example of how traditional historiography constructs past events. The intertextual aspect of the novel containing borrowings from Freud's works and Anatoli Kuznetsov's Babi Yar attracts the reader's attention to the novel's writing process, which shows that fictional and factual narratives undergo the same process of construction. The multiplicity of literary forms and genres enhances the ambivalence of the reality status of the events and makes the reader question their functions. The multiplicity of the narrators leaves the reader on a slippery ground so that s/he is not sure whether Freud's or Lisa's narration of past events is correct. The presence of Freud and his case history constantly lead the reader to think of the novel as an artefact. The novel employs an anti-linear plot structure since the events do not chronologically proceed successively. The proper beginning, middle, and end structure is disturbed by employing an arbitrary and unsuitable ending in The White Hotel. This way of constructing the novel, which makes use of many unconventional techniques to draw attention to the writing process, makes the novel highly self-reflexive. The narrative techniques employed foreground how the traditional novelist creates the illusion that what s/he represents corresponds to the truth. Furthermore, the novel uses historical figures and events and creates confusion as to the boundary between fact and fiction in order to undermine historical representation both in fictional and nonfictional historical writings. Thus, D. M. Thomas breaks the conventions of traditional historical fiction and undermines traditional methods of historiography in The White Hotel.

\section{References}


Amis, Martin (2002). The D. M. Thomas Phenomenon. In Martin Amis, The War against Cliché: Essays and Reviews 1971-2000 (pp. 141-145). London: Vintage, 2002.

Brown, Lady F. (1985). The White Hotel: D. M. Thomas's Considerable Debt to Anatoli Kuznetsov and Babi Yar. South central review 2(2), 60-79.

Butler, Christopher (2002). Postmodernism: A Very Short Introduction. Oxford: Oxford UP.

Butter, Micheal (2011). Historiographic metafiction. In Brian W. Shaffer (Ed.) The Encyclopedia of Twentieth-century fiction (pp. 626-630). Chichester: Wiley-Blackwell. Catholic Encyclopedia (2012). Retrieved 13 Aug 2016 from: http://www.newadvent.org/cathen/.

Eaglestone, Robert (2004). The Holocaust and the postmodern. New York: Oxford UP.

Fowles, John (1969). The French Lieutenant's woman. Boston: Little, Brown.

Hutcheon, Linda (1988). A Poetics of postmodernism: History, Theory, Fiction. London: Routledge.

Hutcheon, Linda (1986). Subject in/of/to History and His Story. Diacritics 16(1), 78-91.

Kahn, Sharon K. (1996). Ferenczi's Mutual Analysis: A Case Where the Messenger was Killed and his Treasure Buried. Retrieved 02 Aug 2016 from: http://pandc.ca/?cat= sigmund_freud\&page=ferenczi_mutual_analysis.

Kurca, Mustafa (2009). Postmodern historical novels: jeanette winterson's and salman rushdie's novels as historiographic metafictions. Retrieved 10 Jan 2016 from: http://library.metu.edu.tr/search S4?/Xmustafa+k $\{\mathrm{u} 0131\} \mathrm{rca} \& S O R T=D / X m u s t a f a+k$ $\{\mathrm{u} 0131\} \mathrm{rca} \& \mathrm{SORT}=\mathrm{D} \& \mathrm{SUBKEY}=$ mustafa $+\mathrm{k} \% \mathrm{C} 4 \% \mathrm{~B} 1 \mathrm{rca} / 1 \% 2 \mathrm{C} 8 \% 2 \mathrm{C} 8 \% 2 \mathrm{CB} / \mathrm{fram}$ eset\&FF=Xmustafa+k $\{\mathrm{u} 0131\} \mathrm{rca} \& S O R T=\mathrm{D} \& 5 \% 2 \mathrm{C} 5 \% 2 \mathrm{C}$.

Kuznetsov, A. Anatoli (1970). Babi Yar. Trans. David Floyd. New York: Washington square press.

Lougy, Robert E. (1991). The Wolf Man, Freud and D. M. Thomas: Intertextuality, Interpretation, and narration in the white hotel. Modern language studies 21(3), 91-106.

Oppermann, Serpil (2006). Postmodern tarih kurami: Tarih yazimi, yeni tarihselcilik ve roman. Ankara: Phoenix.

Quinn, Edward (2004). History in literature: A reader's guide to 20th-century history and the literature It inspired. New York: Facts on file inc.

Rushdie, Salman (1981). Midnight's children. London: Picador.

Swinden, Patrick (1982). D. M. Thomas and the white hotel. Critical quarterly 24(4), 74-80.

Tanner, Laura E. (1991). Sweet Pain and Charred Bodies: Figuring violence in The white hotel. Boundary 2. 18(2), 130-149.

Thomas, D. M. (1983). Freud and The White Hotel. British medical journal (Clinical research edition) 287(6409), 1957-1960.

Thomas, D. M. (1981). The white hotel. New York: Penguin.

Vice, Sue (2010). Holocaust fiction. London: Routledge.

Vieira, Gregory C. (1993) No place for Utopia: Postmodern Theory and The white hotel. Utopian Studies 4(2), 117 - 127.

Waugh, Patricia (1984). Metafiction: The theory and practice of self-conscious fiction. London: Methuen.

White, Hayden V. (1978). Tropics of discourse: Essays in cultural criticism. Baltimore: Johns Hopkins UP. 